\title{
PENERAPAN NAIVE BAYES UNTUK PENERIMAAN BEASISWA
}

\author{
Delpiah Wahyuningsih ${ }^{1}$, Eli Patima ${ }^{2}$ \\ ${ }^{1,2}$ Program Teknik Informatika \\ STMIK Atma Luhur Pangkalpinang \\ Email: delphibabel@atamaluhur.ac.id ${ }^{1}$,elycst@gmail.com²
}

\begin{abstract}
ABSTRAK
SMA Negeri 4 Pangkalpinang adalah salah satu sekolah negeri yang memiliki program beasiswa. Beasiswa yang ada di SMA Negeri 4 Pangkalpinang terbagi menjadi 2 yaitu Beasiswa Prestasi dan Beasiswa Kurang Mampu. Dalam memberikan beasiswa harus dilakukan proses secara selektif agar sesuai dengan jenis beasiswa yang didapat. Setiap beasiswa memiliki syarat-syarat atau ketentuan yang harus dipenuhi. Proses penerimaan beasiswa yang ada di SMA Negeri 4 Pangkalpinang masih bersifat inefisien dikarenakan dalam proses penerimaan beasiswa hasil seleksi kurang akurat karena hanya mengandalkan pengamatan dengan indera penglihatan (visual) dan apabila kondisi lelah maka rentan terjadi kesalahan (human error). Tujuan dari penelitian ini adalah menganalisis penerapan algoritma naive bayes untuk perancangan sistem penerimaan beasiswa pada SMA Negeri 4 Pangkalpinang, mengetahui kelemahan yang ada dalam proses penerapan algoritma naive bayes untuk penerimaan beasiswa pada SMA Negeri 4 Pangkalpinang. Naive Bayes merupakan sebuah pengklasifikasian probabilistik sederhana yang menghitung sekumpulan probabilitas dengan menjumlahkan frekuensi dan kombinasi nilai dari data set yang diberikan. Dalam penelitian ini akan menghasilkan sebuah Penerapan Algoritma Naive Bayes Untuk Penerimaan Beasiswa Pada SMA Negeri 4 Pangkalpinang. Hasil dari pengimplementasian sistem ini dapat memudahkan pihak sekolah dalam proses penerimaan beasiswa.
\end{abstract}

Kata kunci: Algoritma Naive Bayes, Penerimaan Beasiswa, Sistem Penunjang Keputusan

\begin{abstract}
SMA Negeri 4 Pangkalpinang is one of the public schools that have a scholarship program. The scholarship in SMA Negeri 4 Pangkalpinang is divided into 2, namely Achievement Scholarship and Undergraduate Scholarship. In giving scholarships a selective process must be done to fit the type of scholarship earned. Each scholarship has terms or conditions that must be met. The process of acceptance of scholarship in SMA Negeri 4 Pangkalpinang still inefisien because in the process of acceptance of scholarship result of selection less accurate because only relying on observation with senses of sight (visual) and if condition tired then susceptible error (human error). The purpose of this research is to analyze the application of naive bayes algorithm for the design of scholarship receiving system at SMA Negeri 4 Pangkalpinang, to know the
\end{abstract}


weaknesses that exist in the process of applying naive bayes algorithm for scholarship acceptance at SMA Negeri 4 Pangkalpinang. Naive Bayes is a simple probabilistic classifier that computes a set of probabilities by summing the frequency and value combinations of the given data sets. In this research will produce an Application of Naive Bayes Algorithm for Scholarship Acceptance at SMA Negeri 4 Pangkalpinang. The results of the implementation of this system can facilitate the school in the process of receiving scholarships.

Keyword: Naive Bayes Algorithm, Scholarship Reception, Decision Support System

\section{PENDAHULUAN}

Beasiswa adalah pemberian berupa bantuan keuangan yang diberikan kepada perorangan yang bertujuan untuk digunakan demi keberlangsungan pendidikan yang ditempuh.Pemberian beasiswa dilakukan untuk membantu siswa dalam meraih cita-cita dan dengan harapan siswa tersebut memperoleh prestasi yang baik, selain itu juga untuk membantu siswa yang kurang mampu. Dalam memberikan beasiswa harus dilakukan proses secara selektif agar sesuai dengan jenis beasiswa yang didapat. Setiap beasiswa memiliki syarat - syarat atau ketentuan yang harus dipenuhi. Setiap sekolah ada beasiswa yang diberikan kepada siswa-siswa, salah satu sekolah yang memberikan beasiswa yaitu SMA N 4 Pangkalpinang.

Beasiswa yang ada di SMA N 4 Pangkalpinang terbagi menjadi 2 yaitu Beasiswa Prestasi dan Beasiswa Kurang Mampu. Beasiswa Prestasi dilakukan melalui program KIP yaitu Kartu Indonesia Pintar dan untuk siswa yang kurang mampu melalui SKTM (Surat Keterangan Tidak Mampu). Proses penerimaan beasiswa yang ada di SMA N 4 Pangkalpinang masih bersifat inefisien dikarenakandalam proses penerimaan beasiswa hasil seleksi kurang akurat karena hanya mengandalkan pengamatan dengan indera penglihatan (visual) dan apabila kondisi lelah maka rentan terjadi kesalahan (human error).

Dengan perkembangan teknologi komputer yang pesat dapat memudahkan dalam hal melakukan pekerjaan, selain itu manfaatnya telah dirasakan oleh semua kalangan dari anak kecil sampai lanjut usia. Perkembangan teknologi komputer khususnya teknologi informasi dalam android dapat membentuk suatu aplikasi 
untuk pendidikan khususnya beasiswa yang menjadi suatu revolusi dibidang informasi berbasis teknologi internet dan dapat dijadikan alternatif bagi pengembangan sistem informasi dengan biaya rendah.

Naive Bayes merupakan salah satu algoritma yang melakukan pengklasifikasian dengan metode probabilitas dan statistik yang dikemukakan oleh ilmuwan Inggris Thomas Bayes dalam memprediksi peluang di masa depan berdasarkan pengalaman di masa sebelumnya sehingga dikenal sebagai Teorema Bayes. Dengan menggunakan algoritma naive bayes dapat mencegah terjadinya kesalahan dalam melakukan perhitungan penerimaan beasiswa dan dapat menghasilkan perhitungan yang akurat (Rahman, Antony Anwari dan Suryanto Agus).

\section{METODE PENELITIAN}

\section{Naive Bayes}

Naive Bayes merupakan sebuah pengklasifikasian probabilistik sederhana yang menghitung sekumpulan probabilitas dengan menjumlahkan frekuensi dan kombinasi nilai dari data set yang diberikan. Naive Bayes merupakan pengklarifikasiaan dengan metode probabilitas dan statistik yang dikemukakan oleh ilmuan Inggris Thomas Bayes, yaitu memprediksi peluang di masa depan berdasarkan pengalaman di masa sebelumnya. Metode Naive Bayes juga dinilai berpotensi baik dalam mengklasifikasikan dokumen dibandingkan dengan metode pengklasifikasian lain dalam hal akurasi dan efisiensi komputasi. (Bustami)

persamaan dari teorema Bayes adalah :

Dimana :

$$
\frac{P(X \backslash H) x P(H)}{P(H \backslash X)=p(X)}
$$

$\mathrm{X} \quad$ : Data dengan class yang belum diketahui

$\mathrm{H} \quad$ : Hipotesis data merupakan suatu class yang spesisifik

$\mathrm{P}(\mathrm{H} \backslash \mathrm{X})$ : Probabilistik hipotesis $\mathrm{H}$ berdasar kondisi X (posteriori probabilistik)

$\mathrm{P}(\mathrm{H}) \quad$ : Probabilistik hipotesis $\mathrm{H}$ (prior probabilitas)

$\mathrm{P}(\mathrm{X} \backslash \mathrm{H})$ : Probabilistik hipotesis $\mathrm{X}$ berdasar kondisi pada hipotesis $\mathrm{H}$

$\mathrm{P}(\mathrm{X}) \quad$ : Probabilitas $\mathrm{X}$ 
Untuk menjelaskan teorima Nä̈ve Bayes, perlu diketahui bahwa proses klarifikasi memerlukan sejumlah petunjuk untuk menentukan kelas apa yang cocok bagi sampel yang dianalis tersebut. Karena itu, teorema Bayes di atas disesuaikan sebagai berikut :

$$
P\left(C \mid F_{1} \ldots F_{n}\right)=\frac{P(C) P\left(F_{1} \ldots F_{n} \mid C\right)}{P\left(F_{1} \ldots F_{n}\right)}
$$

Dimana variabel $\mathrm{C}$ mempresentasikan kelas, sementara variabel $\mathrm{F} 1$... $\mathrm{Fn}$ mempresentasikan karakteristik petunjuk yang dibutuhkan untuk melakukan klasifikasi. Maka rumus tersebut menjelaskan bahwa peluang masuknya sampel karakteristik tertentu dalam kelas C (Posterior) adalah peluang munculnya kelas C (sebelum masuknya sampel tersebut, seringkali disebut prior), dikali dengan peluang kemunculan karakteristik - karakteristik sampel pada kelas C (disebut juga likelilhood), dibagi dengan peluang kemunculan karakteristik - karakteristik sampel secara global (disebut juga avidence). Karena itu, rumus diatas dapat pula ditulis secara sederhana sebagai berikut :

$$
\text { Posterior }=\frac{\text { Prior } x \text { likelihood }}{\text { evidence }}
$$

Nilai Evidence selalu tetap untuk setiap kelas pada satu sampel. Nilai dari posterior tersebut nantinya akan dibandingkan dengan nilai - nilai posterior kelas lainnya untuk menentukan ke kelas apa suatu sampel akan diklasifikasikan. Penjabaran lebih lanjut rumus Bayes tersebut dilakukan dengan menjabarkan $(\mathrm{C} / \mathrm{F} 1, \ldots, \mathrm{Fn})$ menggunakan aturan perkalian sebagai berikut:

$$
\begin{aligned}
P(C \mid & \left.F_{1}, \ldots, F_{n}\right)=P(C) P\left(F_{1}, \ldots, F_{n} \mid C\right) \\
& =P(C) P\left(F_{1} \mid C\right) P\left(F_{2}, \ldots, F_{n} \mid C, F_{1}\right) \\
& =P(C) P\left(F_{1} \mid C\right) P\left(F_{2} \mid C, F_{1}\right) P\left(F_{3}, \ldots, F_{n} \mid C, F_{1}, F_{2}\right) \\
& =P(C) P\left(F_{1} \mid C\right) P\left(F_{2} \mid C, F_{1}\right) P\left(F_{3} \mid C, F_{1}, F_{2}\right), P\left(F_{4}, \ldots, F_{n} \mid C, F_{1}, F_{2}, F_{3}\right) \\
& =P(C) P\left(F_{1} \mid C\right) P\left(F_{2} \mid C, F_{1}\right) P\left(F_{3} \mid C, F_{1}, F_{2}\right) \ldots P\left(F_{n} \mid C, F_{1}, F_{2}, F_{3}, \ldots, F_{n-1}\right)
\end{aligned}
$$


Dapat dilihat bahwaha silpenjabaran tersebut menyebabkan semakin banyak dan semakin kompleksnya factor - factor syarat yang mempengaruhi nilai probabilitas, yang hamper mustahil untuk dianalisa satu persatu. Akibatnya, perhitungan tersebut menjadi sulit untuk dilakukan. Disinilah digunakan asumsi independensi yang sangat tinggi (naif), bahwa masing- masing petunjuk (F1, F2, ..., Fn) saling bebas (independen) satu sama lain. Dengan asumsi tersebut, maka berlaku suatu kesamaan sebagai berikut:

$$
\begin{gathered}
P\left(P_{i} \mid F_{j}\right)=\frac{P\left(F_{i} \cap F_{j}\right)}{P\left(F_{j}\right)}=\frac{P\left(F_{i}\right) P\left(F_{j}\right)}{P\left(F_{j}\right)}=P\left(F_{i}\right) \\
\text { Untuk } i \neq j, \text { sehingga } \\
P\left(F_{i} \mid C, F_{j}\right)=P\left(F_{i} \mid C\right)
\end{gathered}
$$

Dari persamaan di atas dapat disimpulkan bahwa asumsi independen sinaif tersebut membuat syarat peluang menjadi sederhana, sehingga perhitungan menjadi mungkin untuk dilakukan. Selanjutnya, penjabaran $\mathrm{P}(\mathrm{C} / \mathrm{F} 1, \ldots, \mathrm{Fn})$ dapat disederhan akan menjadi :

$$
\begin{gathered}
P\left(C \mid F_{1}, \ldots, F_{n}\right)=P(C) P\left(F_{1} \mid C\right) P\left(F_{2} \mid C\right) P\left(F_{3} \mid C\right) \ldots \\
=P(C) \prod_{i=1}^{n} P\left(F_{i} \mid C\right)
\end{gathered}
$$

Persamaan di atas merupakan model dari teorema Naive Bayes yang selanjutnya akan digunakan dalam proses klasifikasi. Untuk klasifikasi dengan data kontinyu digunakan rumus Densitas Gauss :

$$
P\left(X_{i}=x_{i} \mid Y=y_{j}\right)=\frac{1}{\sqrt{2 \pi \sigma_{i j}}} e^{-\frac{\left(x_{i}-\mu_{i j}\right)^{2}}{2 \sigma^{2} i j}}
$$

Keterangan :

$\mathrm{P} \quad$ : Peluang.

$\mathrm{Xi}$ : Atributkei.

$\mathrm{Xi} \quad$ : Nilai atribut ke $\mathrm{i}$.

Y : Kelas yang dicari.

yi : Sub kelas I yang dicari.

u : Mean, menyatakan rata - rata dari semua atribut.

o : Deviasi standar, menyatakan varian dari seluruh atribut. (Sitohang, F) 


\section{Penelitian Terdahulu}

Pertama dari Hesham Mohamed MA Al Laroussi, Implementasi Algoritma Naive Bayes Sebagai Proses Seleksi Penerima Beasiswa Libyan Embassy Berbasis Web.Penelitian ini sanggup menerapkan algoritma Naive Bayes dalam proses penyeleksian penerima beasiswa Libyan embassy dengan akurasi $88.3 \%$ dari 60 sampel mahasiswa yaitu sebanyak 7 hasil yang tidak sesuai dan 53 hasil yang sesuai. Kedua dari Rizal Amegia Saputra dan Shinta Ayuningtias, Penerapan Algoritma Naive Bayes Untuk Penelitian Calon Penerima Beasiswa Pada SMK Pasim Plus Sukabumi.Dalam penelitian ini digunakan penelitian dengan metode eksperimen dengan menggunakan data siswa yang mengajukan beasiswa di "SMK Pasim Plus Sukabumi" sejumlah 68 orang, yang terdiri dari 25 siswa yang dinyatakan lulus seleksi dan 43 diantaranya yang dinyatakan tidak lulus seleksi. Ketiga dari Wisnu Uriawan dan Gina Zaida Yusfira, Prediksi Penerima Beasiswa Pegawai Menggunakan Metode Naive Bayes Cllassifier.Dengan adanya aplikasi prediksi penerima beasiswa pegawai, proses penentuan yang dilakukan terlaksana dengan cara yang lebih objektif. Keempat dari RianiDewi H, Yunita, dan Novi Indrawati, Rancang Bangun Sistem Pendukung Keputusan Penerimaan Beasiswa Menggunakan Metode Naive Bayes Classiffier. Metode Naive Bayes Classiffier memberikan proses penyeleksian yang cepat dan algoritmanya mudah dimengerti. Kelima dari Yusuf Zakariya, Implementasi Metode Naive Bayes Dalam Penentuan Kelayakan Penerima Bantuan Siswa Miskin. Sistem penentuan kelayakan penerima bantuan siswa miskin dengan metodenaive bayes dapat dirancang dengan bahasa pemrograman C Sharp dan database mysql.

\section{Data Training}

Data Training merupakan data yang digunakan oleh algoritma klasifikasi untuk membentuk sebuah model classifier. Data training yang digunakan untuk proses perhitungan layak atau tidak layak nya pada SMA Negeri 4 Pangkalpinang adalah sebagai berikut : 
Tabel 1. Data Training

\begin{tabular}{|l|l|l|l|}
\hline No & Data & Keterangan & Range \\
\hline 1 & \multirow{2}{*}{ Nilai Raport } & Rendah & $0-65$ \\
\cline { 3 - 4 } & & Sedang & $66-80$ \\
\cline { 3 - 4 } & & Tinggi & $81-100$ \\
\hline 2 & \multirow{2}{*}{ Status Orangtua } & Layak & Bercerai \\
\cline { 3 - 4 } & & Tidak & Tidak Bercerai \\
& & Layak & \\
\hline 3 & \multirow{2}{*}{ Jumlah } & Rendah & $0-2$ \\
\cline { 3 - 4 } & Tanggungan & Sedang & $3-4$ \\
\cline { 3 - 4 } & & Tinggi & $>=5$ \\
\hline 4 & Penghasilan & Rendah & $0-750.000$ \\
\cline { 3 - 4 } & Orangtua & Sedang & 750.000 \\
& & & 2.500 .000 \\
\cline { 3 - 4 } & & Tinggi & $>=2.500 .000$ \\
\hline
\end{tabular}

\section{Data Testing}

Data testing merupakan data yang akan menampilkan skor atau nilai dari data training. Dimana akan menghasilkan layak atau tidak layak nya siswa untuk mendapatkan beasiswa serta tampil data rekomendasi hasil layak atau tidak layak. Data testing yang diterapkan pada sistem beasiswa SMA Negeri 4 Pangkalpinang sebagai berikut:

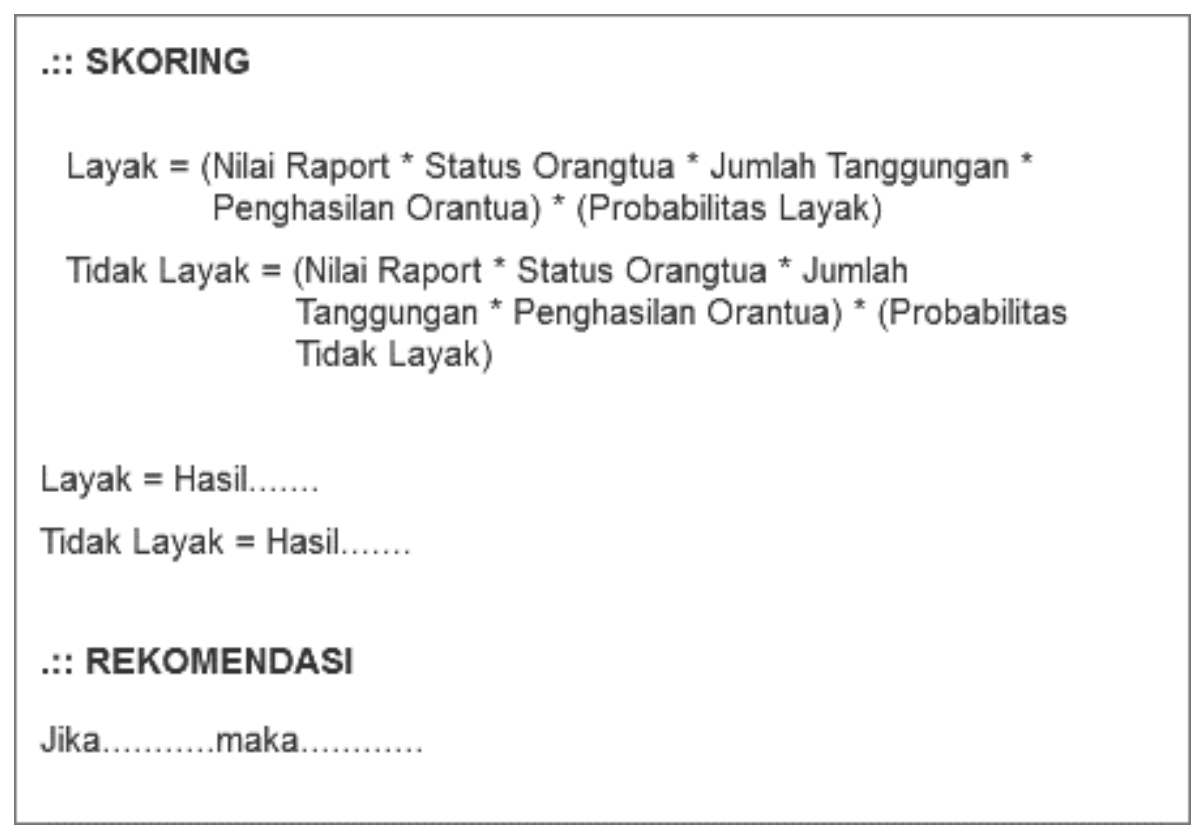

Gambar 1. Data Testing 


\section{Sistem Usulan dari sisi Client}

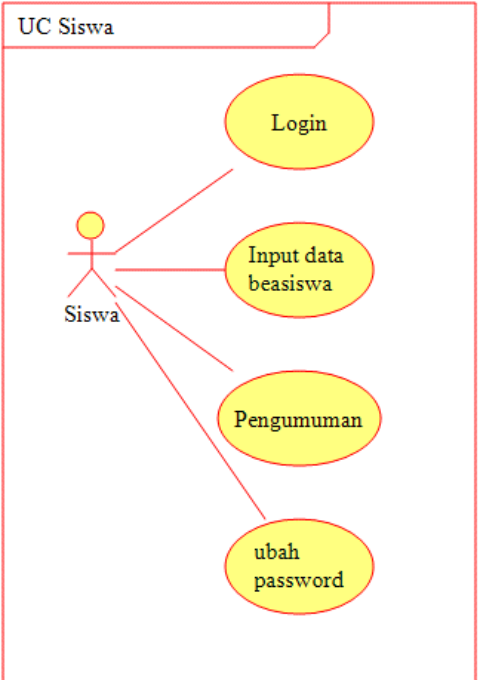

Gambar 2. Sistem usulan sisi client

\section{Sistem Usulan dari sisi Server}

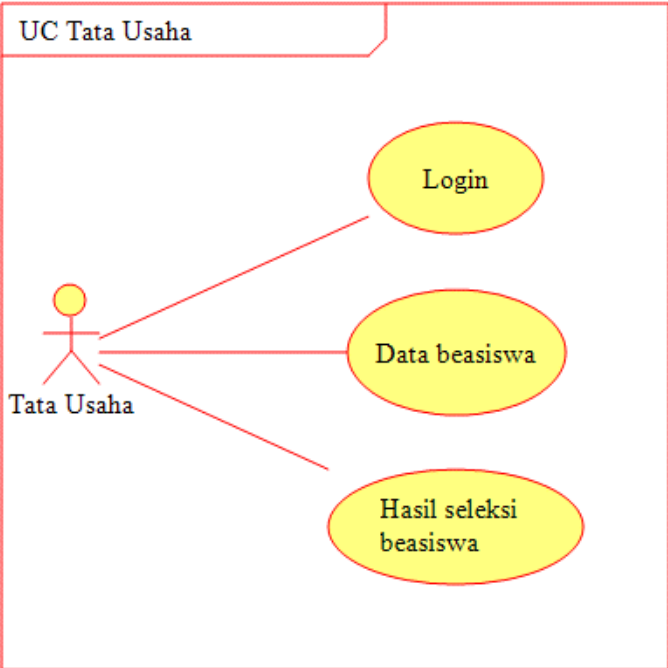

Gambar 3. Sistem Usulan Server 


\section{Sequence Diagram}

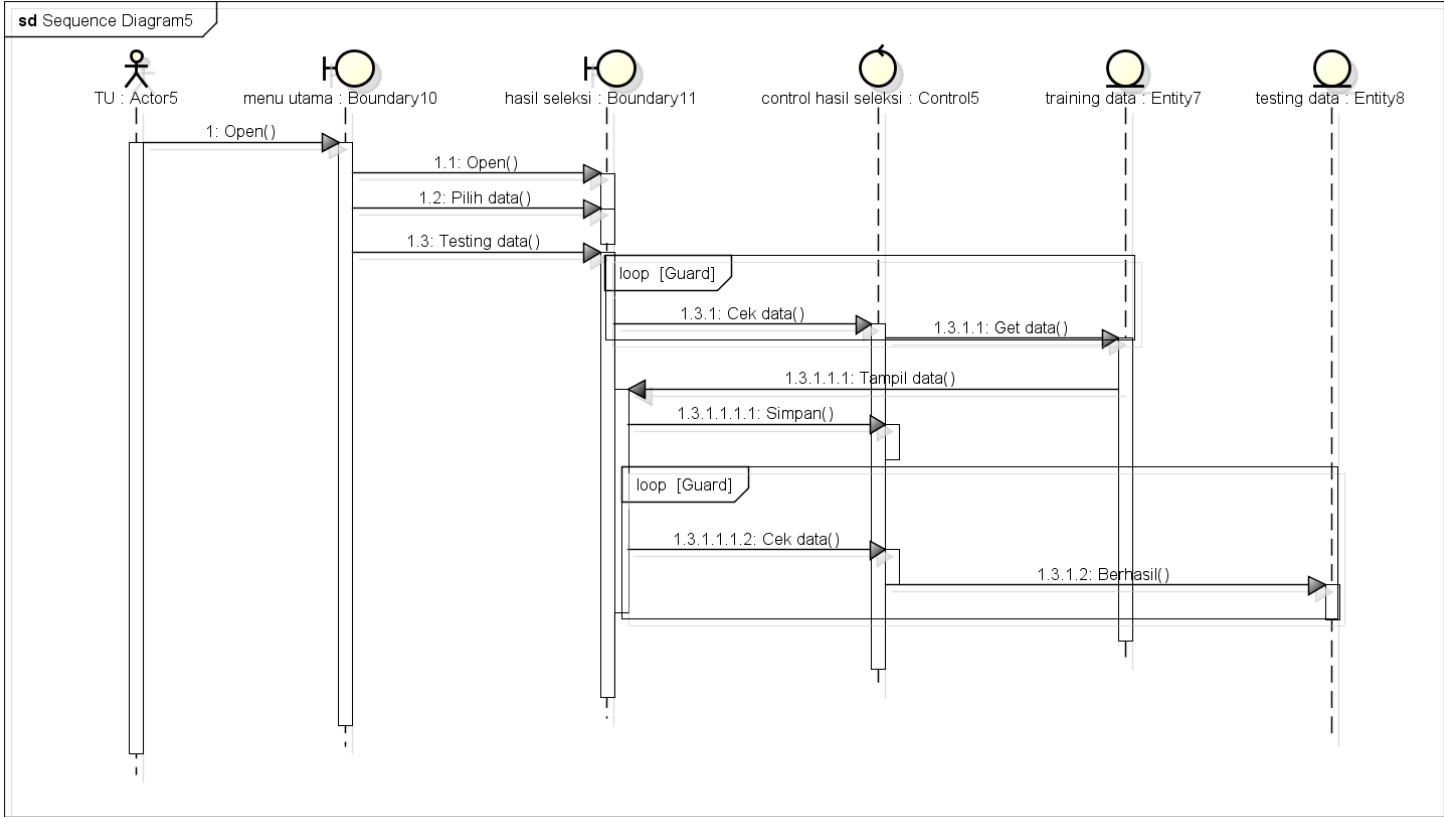

Gambar 4. Sequence Diagram

\section{HASIL DAN PEMBAHASAN}

\section{Tampilan dari sisi Client}

Client membuka aplikasi yang tersedia pada smartphone berbasis android yang telah terinstal pada masing-masing siswa, masukkan username dan password kemudian tampil menu seperti gambar 5.

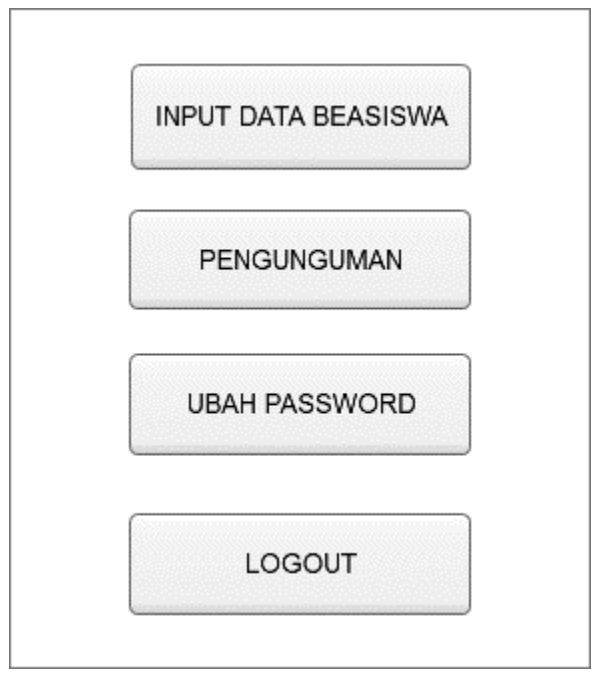

Gambar 5 Menu Client 
Pertama, Client akan menginput data beasiswa yang akan di isi berupa data pribadi dan data pendukung beasiswa seperti gambar 6

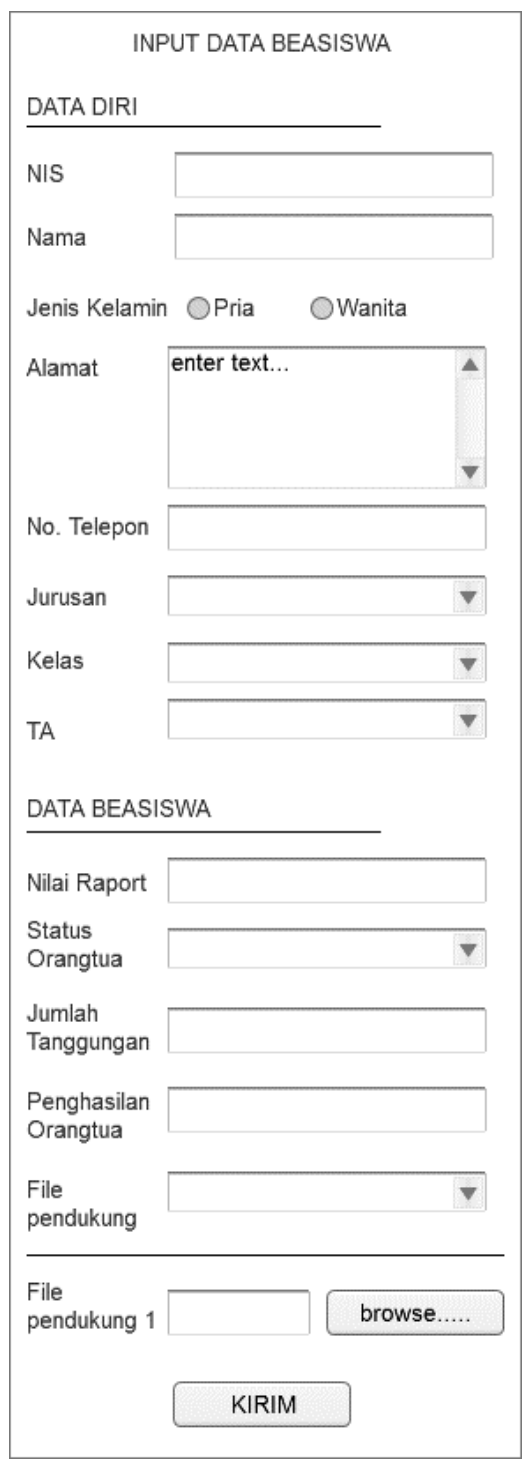

Gambar 6 Data Beasiswa

\section{Tampilan dari sisi server}

Sisi server yang mengelola data beasiswa yaitu data beasiswa masuk, periode serta mengelola data dengan naive bayes yaitu tahapan training (data beasiswa) dan testing (mengelola hasil dari tahapan training) 


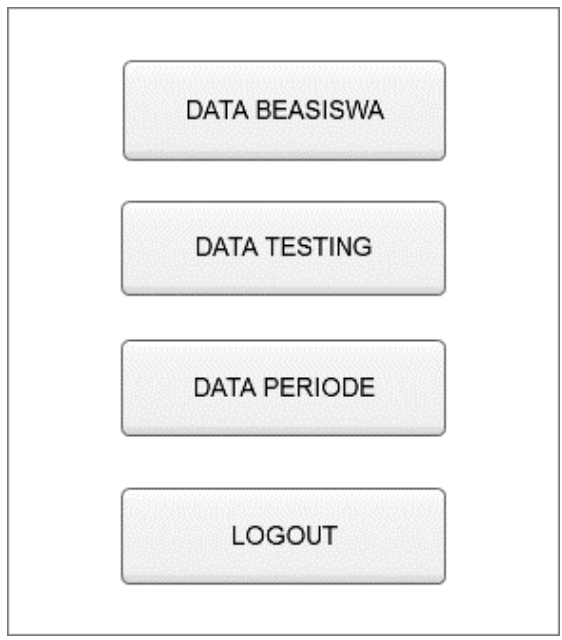

Gambar 7. Menu Server

\begin{tabular}{|c|c|c|c|c|c|c|c|c|c|}
\hline \multirow{3}{*}{$\begin{array}{l}\text { Data beasiswa } \\
\text { Data periode } \\
\text { Data testing }\end{array}$} & \multicolumn{9}{|c|}{ Home logo } \\
\hline & No & NIS & Nama & $\begin{array}{c}\text { Nilai } \\
\text { Raport }\end{array}$ & $\begin{array}{c}\text { Status } \\
\text { Orang } \\
\text { tua }\end{array}$ & $\begin{array}{c}\text { Jumlah } \\
\text { Tanggungan }\end{array}$ & $\begin{array}{c}\text { Penghasilan } \\
\text { Orangtua }\end{array}$ & Kelayakan & Aksi \\
\hline & 1 & $x x x x$ & $x x x x$ & 999 & $\mathrm{xxxx}$ & 999 & 999 & Layak/Tidak Layak & Ubah Hapus \\
\hline
\end{tabular}

Gambar 8 Data Beasiswa

Data beasiswa merupakan tahapan training ketika siswa mengisi data dan mengklik data simpan maka pada kodingan di proses sesuai dengan tabel 1.

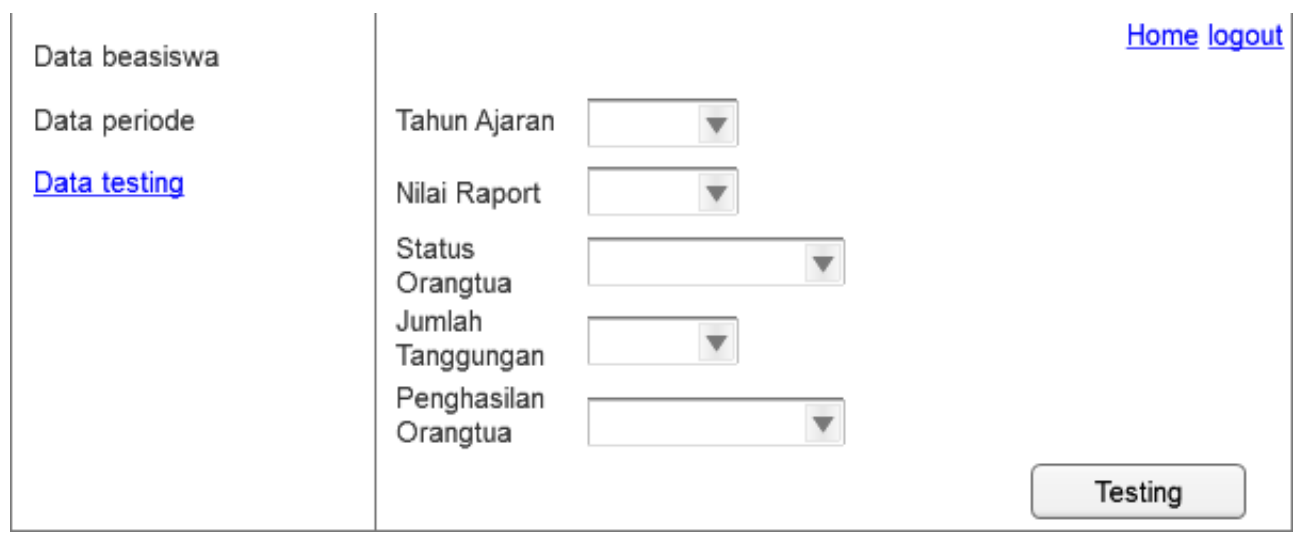

Gambar 9 Data Testing 
Pada gambar 9 menjelaskan dimana admin memilih data dan memproses ketahapan testing, ketika di proses sesuai dengan gambar 1 maka akan menampilkan hasil layak atau tidak layak

\begin{tabular}{|c|c|c|}
\hline NIS & Nama & Kelayakan \\
\hline 12345 & Safitri & Layak \\
\hline 23456 & Agus Firza & Tidak Layak \\
\hline \multicolumn{3}{|c|}{ Oke } \\
\hline
\end{tabular}

Gambar 10 Hasil Data Testing

\section{SIMPULAN}

1. Sistem beasiswa ditentukan dengan beberapa kriteria yaitu nilai raport, status orangtua, jumlah tanggungan, dan penghasilan orangtua untuk membantu proses perhitungan.

2. Terapan Naive Bayes pada sistem ini dengan dua tahapan yaitu pertama menggunakan data training yang telah di transformasi ke dalam bentuk numerik, selanjutnya dicari nilai korelasi dan data tersebut ditesting kemudian akan menampilkan hasil dari perhitungan Naive Bayes.

3. Naive Bayes memberikan kemudahan kepada sekolah terutama bagian tata usaha dalam pengambilan keputusan untuk siswa yang berhak menerima beasiswa, hasil akhir dari metode ini mengeluarkan siapa yang layak atau tidak layak untuk mendapatkan beasiswa.

\section{DAFTAR PUSTAKA}

Bustami.Penerapan Algoritma Naïve Bayes untuk mengklasifikasikan data Nasabah asuransi. Teknik Informatika Universitas Malikussaleh.

Hesham Mohamed MA Al Laroussi. 2015. Implementasi Algoritma Naive Bayes Sebagai Proses Seleksi Penerima Beasiswa Libyan Embassy Berbasis Web. Universitas Islam Negeri Maulana Malik Ibrahim Malang.

Rahman, Antony Anwari dan Suryanto Agus.2017.Implementasi Sistem Informasi Seleksi Penerimaan Beasiswa Dengan Metode Naive Bayes Classifier. 
Jurnal Penelitian Pendidikan Indonesia (JPPI) Vol 2 Nomor 3.Universitas Negeri Semarang.

RianiDewi H, Yunita, dan Novi Indrawati. 2008. Rancang Bangun Sistem Pendukung Keputusan Penerimaan Beasiswa Menggunakan Metode Naive Bayes Classiffier. Teknik Informatika Fakultas Teknik Universitas Trunojoyo Madura.

Rizal Amegia Saputra dan Shinta Ayuningtias. 2016. Penerapan Algoritma Naive Bayes Untuk Penelitian Calon Penerima Beasiswa Pada Smk Pasim Plus Sukabumi. STMIK Nusa Mandiri.

Sitohang, F.2013. Sistem pendukung keputusan Penerimaan beasiswa dengan metode TOPSIS. Pelita Informatika Budi Darma.

Wahyudi, Rizki dan Utami, Ema. 2016. Sistem Pakar E-Tourism Pada Dinas Pariwisata D.I.Y Menggunakan Metode Forward Chaining. Jurnal Ilmiah Dasi Vol. 17 No. 2. ISSN: 1411-3201.

Wisnu Uriawan dan Gina Zaida Yusfira. 2016. Prediksi Penerima Beasiswa Pegawai Menggunakan Metode Naive Bayes Cllassifier. Program studiSistemInformasi STMIK LPKIA.

Yusuf Zakariya. 2017. Implementasi Metode Naive Bayes Dalam Penentuan Kelayakan Penerima Bantuan Siswa Miskin. Fakultas Teknik Universitas Nusantara PGRI Kediri 